\begin{tabular}{|c|c|}
\hline Title & $\begin{array}{l}\text { Effect of granul ocyte colony-stimulating factor on IL- } 12 \text { p } 40 \text { production during chemotherapy for B-cell lineage non- } \\
\text { Hodgkin's lymphoma patients }\end{array}$ \\
\hline Author(s) & $\begin{array}{l}\text { Toubai, Tomomi; Tanaka, Junji; Ota, Shuichi; Fukuhara, Takashi; Hashino, Satoshi; Kondo, Takeshi; Shono, Y Ysuke; } \\
\text { Morioka, Masanobu; Kawamura, T sugumichi; Masauzi, Nobuo; Kakinoki, Y Yasutaka; Kobay ashi, Hajime; Kunieda, } \\
\text { Y asuyuki; Kasai, Masaharu; Kurosawa, Mitsutoshi; A saka, Masahiro; Imamura, Masahiro }\end{array}$ \\
\hline Citation & $\begin{array}{l}\text { European Journal Of Haematology, } 77(5), 403-409 \\
\text { https://doi.org/10.1111/.1600-0609.2006.00746.x }\end{array}$ \\
\hline Issue Date & $2006-11$ \\
\hline Doc URL & http:/hdl. handle.net/2115/30221 \\
\hline Rights & The definitive version is available at www.blackwell-synergy.com \\
\hline Type & article (author version) \\
\hline File Information & EJH77-5.pdf \\
\hline
\end{tabular}

Instructions for use 


\title{
Effect of granulocyte colony-stimulating factor on IL-12 p40 production during chemotherapy for B-cell lineage Non-Hodgkin's lymphoma patients
}

\author{
Tomomi Toubai ${ }^{1)}$, Junji Tanaka ${ }^{1)}$, Shuichi Ota ${ }^{2)}$, Takashi Fukuhara ${ }^{3)}$, Satoshi Hashino ${ }^{2)}$, Takeshi \\ Kondo $^{2)}$, Yusuke Shono' ${ }^{1)}$, Masanobu Morioka ${ }^{4)}$, Tsugumichi Kawamura ${ }^{5)}$, Nobuo Masauzi ${ }^{6)}$, \\ Yasutaka Kakinoki ${ }^{7}$, Hajime Kobayashi ${ }^{8)}$, Yasuyuki Kunieda ${ }^{9)}$, Masaharu Kasai ${ }^{10)}$, Mitsutoshi \\ Kurosawa $^{11)}$, Masahiro Imamura ${ }^{1)}$ \\ ${ }^{1)}$ Department of Hematology and Oncology, Hokkaido University Graduate School of Medicine. \\ ${ }^{2)}$ Department of Gastroenterology and Hematology, Hokkaido University Graduate School of \\ Medicine. \\ ${ }^{3)}$ Department of Internal Medicine, Asahikawa City Hospital. \\ ${ }^{4)}$ Department of Internal Medicine, Aiiku hospital. \\ ${ }^{5)}$ Department of Internal Medicine, Hakodate Central Hospital. \\ ${ }^{6)}$ Department of Hematology, Hakodate City Hospital. \\ ${ }^{7)}$ Department of Internal Medicine, Asahikawa Kosei Hospital. \\ ${ }^{8)}$ The fourth department of Internal Medicine, Obihiro Kosei Hospital. \\ 9) Department of Internal Medicine, Wakkanai City Hospital. \\ ${ }^{10)}$ Department of Hematology, Sapporo Hokuyu Hospital. \\ ${ }^{11)}$ Department of Internal Medicine, Sapporo Kosei Hospital.
}

Running title: IL-12 p40 in NHL patients decrease by G-CSF.

Address correspondence to Dr.Tomomi Toubai,

Hematology and Oncology,

Hokkaido University Graduate School of Medicine,

Kita-15, Nishi-7, Kita-ku, Sapporo, 060-8638, Japan.

Tel: +81-11-706-7214, Fax:+81-11-706-7823

E-mail: ttoubai@hkg.odn.ne.jp. 


\section{Abstract}

IL-12 is a 70-kDa cytokine comprised of two disulfide-linked proteins (p35 and p40) and is essential for the initiation of effective immune response. Granulocyte-colony stimulating factor (G-CSF) affects the balance in the production of anti-inflammatory cytokines. We investigated the serum IL-12 p40 and IL-12 Mix (p40 and p70) production in 28 patients with B-cell lineage non-Hodgkin's lymphoma (NHL) treated with chemotherapy (e.g., CHOP regimen) with or without G-CSF administration and 8 healthy volunteers. We found that serum levels of IL-12 p40 $(191.2 \pm 150.0 \mathrm{pg} / \mathrm{ml})$ and IL-12 Mix $(277.4 \pm 274.5 \mathrm{pg} / \mathrm{ml})$ in the patients before chemotherapy were higher than those in the healthy volunteers (IL-12 p40: $76.4 \pm 25.3 \mathrm{pg} / \mathrm{ml}$, IL-12 Mix: $48.5 \pm 33.4 \mathrm{pg} / \mathrm{ml})(\mathrm{p}=0.04$ and 0.02 , respectively). Next, we examined the serum IL-12 p40 and Il-12 Mix levels in 9 patients receiving chemotherapy with administration of G-CSF (CG group, $\mathrm{n}=9$ ) and without G-CSF (C group, n=9). Serum IL-12 p40 and IL-12 Mix levels were decreased on 10 days after chemotherapy in both groups, and those in CG groups were significantly lower than those in C group. These results indicated that administration of G-CSF decreased serum IL-12 p40 and IL-12 Mix levels. Overall survival (OS) at 24 months was not significantly different in the two groups ( $58.3 \%$ in group $\mathrm{C}$ vs $80.0 \%$ in group $\mathrm{CG}, \mathrm{P}=0.67$ ). However, the survival rate of patients at clinical stages III and IV in CG group ( $\mathrm{n}=6,66.0 \%)$ was significantly better than that of patients in C group $(n=4,25.0 \%)(p=0.02)$. Long-term administration of G-CSF appears to influence the survival rate by reducing immunosuppressive IL-12 p40 production.

Key words: IL-12, IL-12 p40, IL-12 p35, non-Hodgkin's lymphoma, G-CSF 


\section{Introduction}

Interleukin (IL)-12 is a heterodimeric cytokine produced by dendritic cells (DCs), macrophages, polymorphonuclear leukocytes, and keratinocytes (1). IL-12 exerts multiple biologic activities that, besides NK cell activation, also include activation of $\mathrm{CD} 8^{+}$cytotoxic $\mathrm{T}$ lymphocytes (CTLs), differentiation of $\mathrm{CD}^{+} \mathrm{T}$ lymphocytes, induction of nitric oxide (NO) production by macrophages, and induction of type 1 responses by Th lymphocyte $(2,3)$. IL-12 has been shown to possess potent anti-tumor activity in a wide variety of murine tumor models (4-8). IL-12 is a 70-kDa cytokine comprised of two disulfide-linked proteins (p35, which is constitutively expressed, and p40, which is inducible)(9). The genes encoding IL-12 p40 and p35 are located on different human and mouse chromosomes (10). The highly coordinated expression of p40 and p35 genes to form IL-12 (also called p70) in the same cell type at the same time is essential for the initiation of effective immune response. The IL-12 p35 subunit is expressed ubiquitously, whereas expression of the p40 subunit is restricted to IL-12-producing cells (11). The homodimer IL-12 p40 has been found in several studies to be a strong antagonist of IL-12-mediated effects, such as NK cell activity and IFN- $\gamma$ production $(12,13)$.

Granulocyte-colony stimulating factor (G-CSF) is a hematopoietic growth factor that stimulates neutrophil proliferation and function (14). In animal models of infections, the administration of G-CSF increased neutrophil count, decreased bacterial load, and improved organ function and survival, as long as G-CSF was given before or, at the latest, immediately after the initiation of infection (15). Therefore, the possibility that G-CSF affects the balance in the production of anti-inflammatory cytokines has been suggested (16-20). In the present study, we investigated the production of IL-12 p40, IL-12 Mix and other cytokines in patients with B-cell lineage non-Hodgkin's lymphoma (NHL) treated with $\underline{\mathrm{CHOP}}$ (cyclophosphamide, adriamycin, vincristine, prednisolone) regimen with or without G-CSF 
administration. 


\section{Patients and methods}

\section{Preclinical study}

Serum levels of IL-12 p40 and IL-12 Mix were examined in 8 healthy volunteer and 28 patients with malignant lymphoma. Eleven of the 28 patients were clinical stage I - II , and the other patients were clinical stage III-IV .

\section{Patients'characteristics}

Eighteen adult patients with B-cell lineage NHL were registered in the study between January 1999 to June 2003 at Hokkaido University Hospital and 10 other hospitals. All of the patients were informed of the purpose of the study, which was approved by the institutional review board. The characteristics of the 18 patients are summarized in Table 1 . The 18 patients included 10 males and 8 females with a median age of 54 (range, 31-81) years. Patient's performance status (PS) and clinical stage at diagnosis were $0(n=10), 1(n=5), 2(n=0) 3(n=2), 4(n=1)$ and $\quad I(n=3), \quad I(n=5)$, III ( $\mathrm{n}=4), \mathrm{IV}(\mathrm{N}=6)$, respectively. Three patients showed B-symptoms. Malignancy grading according to the working formulation classification was low grade in 6 patients and intermediate grade in 12 patients. All of the patients received CHOP regimen (cyclophosphamide $750 \mathrm{mg} / \mathrm{m}^{2}$ on day 1 , doxorubicin hydrochloride $50 \mathrm{mg} / \mathrm{m}^{2}$ on day 1 , vincristine sulfate $1.4 \mathrm{mg} / \mathrm{m}^{2}$ day 1 , prednisolone $40 \mathrm{mg} / \mathrm{m}^{2}$ on day1-5).

\section{Measurement of serum cytokines}

IL-12 p40 and IL-12 Mix (p40 and p70) were measured in sera collected before chemotherapy and at 10 days and 17 days after chemotherapy. IL-12 p40 and IL-12 Mix were measured in serum by an enzyme-linked immunosorbent assay (ELISA) using commercially available kits (IL-12 p40: R\&D, IL-12 Mix: Endogen). Optical densities were quantified in an ELISA reader and results 
expressed in $\mathrm{pg} / \mathrm{ml}$.

\section{Statistical analysis}

Differences between groups were analyzed by Student's $t$ test. Survival curves were plotted according to the method of Kaplan and Meier, and comparison of the curves was performed using the log-rank test. Overall survival (OS) was measured from the date of registration until death or last contact. Event-free survival (EFS) was measured from the date of registration until relapse after $\mathrm{CR}$, death $\mathrm{CR}$, or last contact, whichever occurred first. If a patient did not reach $\mathrm{CR}$ by induction chemotherapy, EFS was set at 0. Disease-free survival (DFS) was restricted to patients who achieved CR and was measured from attainment of CR until the date of relapse, death, or last contact, whichever occurred first. 


\section{Results}

Serum IL-12 p40 and IL-12 Mix levels were increased in patients with non-Hodgkin's lymphoma.

We found that serum IL-12 p40 and IL-12 Mix levels in NHL patients before chemotherapy were higher than those in healthy volunteers (Table 2). Serum IL-12 p40 and IL-12 Mix levels in healthy volunteers $(\mathrm{n}=8)$ were $76.4 \pm 25.3 \mathrm{pg} / \mathrm{ml}$ and $48.5 \pm 33.4 \mathrm{pg} / \mathrm{ml}$, respectively, and those in NHL patients before chemotherapy $(\mathrm{n}=28)$ were $191.2 \pm 150.0 \mathrm{pg} / \mathrm{ml}$ and $277.4 \pm 274.4 \mathrm{pg} / \mathrm{ml}, \mathrm{p}=0.04$ and $\mathrm{p}=0.02$, respectively. The levels in the 17 clinical stage III-IV patients (IL-12 p40: 229.6 \pm 163.7 $\mathrm{pg} / \mathrm{ml}$, IL-12 Mix: $380.2 \pm 304.6 \mathrm{pg} / \mathrm{ml}$ ) were significantly higher than those in healthy volunteers $(\mathrm{P}=0.01$ and 0.0059 , respectively).

Administration of G-CSF decreased serum IL-12 p40 and IL-12 Mix levels after chemotherapy. To determine the effect of G-CSF on serum IL-12 p40 and IL-12 Mix levels, the patients were divided into a group administered G-CSF (CG group) and a group not administered G-CSF (C group). As shown in Fig.1, serum IL-12 p40 and IL-12 Mix levels decreased at 10 days after chemotherapy in both groups. However, serum IL-12 p40 and IL-12 Mix levels in CG group (IL-12 p40: from $142.0 \pm 121.8 \mathrm{pg} / \mathrm{ml}$ (34 courses) to $24.6 \pm 27.3 \mathrm{pg} / \mathrm{ml}$ (10 days, 32 courses) and to $103.3 \pm 59.0 \mathrm{pg} / \mathrm{ml}$ (17 days, 22 courses), IL-12 Mix: from $154.2 \pm 156.4 \mathrm{pg} / \mathrm{ml}$ (34 courses) to 13.3 $\pm 17.8 \mathrm{pg} / \mathrm{ml}$ (10 days, 32 courses) and to $97.5 \pm 75.7 \mathrm{pg} / \mathrm{ml}$ (17 days, 22 courses $)$ were significantly lower than those in C group (IL-12 p40: from $168.8 \pm 77.4 \mathrm{pg} / \mathrm{ml}$ (29 courses) to $49.1 \pm 43.2 \mathrm{pg} / \mathrm{ml}$ (10 days, 26 courses) and to $167.8 \pm 67.2 \mathrm{pg} / \mathrm{ml}$ (17 days, 13 courses), IL-12 Mix: from $222.6 \pm$ $93.3 \mathrm{pg} / \mathrm{ml}$ (29 courses) to $48.6 \pm 44.1 \mathrm{pg} / \mathrm{ml}$ (10 days, 26 courses) and to $226.6 \pm 98.2 \mathrm{pg} / \mathrm{ml}$ (17 days, 26 courses) at 10 days and 17 days after chemotherapy (IL-12 p40: $\mathrm{p}=0.011$ (10 days) and $\mathrm{p}=0.006$ (17days), IL-12 Mix: $\mathrm{p}=0.0001$ (10 days) and $\mathrm{p}=0.0001$ (17 days)). These results showed that administration of G-CSF decreased serum IL-12 p40 and IL-12 Mix levels. 
Administration of G-CSF improved the survival of patients with advanced-stage non-Hodgkin's lymphoma who had decreased IL-12 p40 and IL-12 Mix levels.

We analyzed the association of clinical characteristics with IL-12 p40 and IL-12Mix levels. Interestingly, serum IL-12 p40 level in CG group patients with clinical stages III and IV was significantly decreased after chemotherapy $(-95.6 \pm 131.1 \mathrm{pg} / \mathrm{ml})$ (16 courses) compared with that in C group patients with clinical stages III and IV $(-0.1 \pm 35.2 \mathrm{pg} / \mathrm{ml})(10$ courses $)(\mathrm{P}=0.035)$ (Fig.2a). However, serum IL-12 Mix level in CG group patients with clinical stages III and IV was not significantly decreased after chemotherapy $(-132.6 \pm 160.1 \mathrm{pg} / \mathrm{ml})(16$ courses $)$ compared with that in C group patients with clinical stages III and IV (-37.0 $75.2 \mathrm{pg} / \mathrm{ml})$ (10 courses) ( $\mathrm{P}=0.091)$ (Fig.2b). Serum IL-12 p70 levels could not be detected in almost all patients.

We analyzed the association of survival rate with administration of G-CSF. The overall survival (OS) at 24 months was not significantly different in the two groups $(58.3 \%$ in $\mathrm{C}$ group vs $80.0 \%$ in CG group, $\mathrm{P}=0.67$ ) (Figure 3-a). However, the survival rates of G-CSF-treated patients at clinical stages III and IV and of G-CSF-treated patients with intermediate grade were significantly better than those in patients not treated with G-CSF (stages III and IV survival rate: $66.6 \%$ vs $25.0 \%$, $\mathrm{p}=0.02$; intermediate grade survival rate: $75.0 \%$ vs $37.5 \%, \mathrm{p}=0.04$ ) (Figure $3-\mathrm{b}, \mathrm{c}$ ). 


\section{Discussion}

According to the Revised European American Lymphoma (R.E.A.L) classification (21), three types of human B-cell lymphoma originating from naïve, germinal center (CG) and memory B-cells have been identified and designated as mantle cell (MCL), follicular (FL) and marginal zone (MZL) lymphomas, respectively. Airoldi et al. purified malignant B-cells from lymph nodes of MCL, FL and MZL patients and tested then by reverse transcription polymerase chain reaction (RT-PCR) for constitutive expression of IL-12 p35 and p40. All tumors expressed IL-12 p35, whereas IL-12 p40 mRNA was consistently detected in FL and MZL cells but not in MCL cells (22, 23). Schwaller et al. studied IL-12 expression in human lymphomas using predominantly immunohistochemical techniques with mAbs to IL-12 p35, IL-12 p40 and IL-12 p70 and no expression of the IL-12 heterodimer or of its components was detected in the neoplastic cells (24). Studies on IL-12 production by malignant B-cells suggest that the IL-12 p40 gene is constitutively transcribed in some lymphoma entities (FL, MZL), whereas p35 mRNA is always expressed.

In contrast to an early report that few cytokines are expressed in NHL (25), several groups have shown that a wide range of cytokines, at least at a transcriptional level, are expressed in NHL tissue (22, 26-28). The present study highlights the potential significance of the administration of G-CSF affecting IL-12 p40 and IL-12 Mix levels in terms of tumor growth and patient survival. Previous studies reports suggested that IL-12 is only expressed in EBV-associated lymphomas $(24,29)$. However, Jones et al. detected transcripts in $60 \%$ of NHL cases and high levels of p40 were associated with a good prognosis, in those cases, although only a small group was analyzed (30). Although we did not examine cytokine gene expression in the lymphoma cells, serum IL-12 p40 level was reduced in the group administered G-CSF and survival rates of G-CSF-treated patients at clinical stages III and IV were superior to those of patients not treated with G-CSF. Recombinant human granulocyte colony-stimulating factor (rhG-CSF) plays an important role in 
changing the mode of in vivo immune responses from type 1 to type 2 . In vivo pretreatment with rhG-CSF induces type-2 dendritic cells (DC2) (31) and type-2 T helper cells (Th2) (32). Monocytes also increase in rhG-CSF-mobilized blood and suppress $\mathrm{T}$ cell responsiveness in vitro by secreting a potent immunosuppressive cytokine, IL-10 $(33,34)$. The rhG-CSF has an influence at least indirectly through inducing type-2 immune cells (DC2, Th2), which downregulate production by type-1 cells of rejection-associated cytokines such as IFN- $\gamma$, IL-2, TNF- $\alpha$ and IL-12. Egi et al. reported that IL-12p35 expression was greatly inhibited by rhG-CSF treatment in heart allografts by pretransplant host treatment (35). On the other hand, in the same rat heart allograft model, IL-12 p40 was upregulated by rhG-CSF-treated allogeneic blood transfusion but downregulated by transfusion of rhG-CSF-treated isogeneic blood (36). Moreover, Kitayama et al. reported that rhG-CSF pretreatment of rats undergoing heart transplantation was effective in prolonging allograft survival only in tacrolimus treated hosts. Intragraft mRNA expression of interleukin (IL)-12 subunits (p35, p40) at 24 hours after transplantation was significantly downregulated by the addition of rhG-CSF and was associated with suppression of interferon- $\gamma$ levels on day 6 , although other proinflammatory cytokines (TNF- $\alpha$, IL-1 $\beta$, IL-6, IL-18) and anti-inflammatory cytokines (IL-10, TGF- $\beta$ ) were not (37). Under these circumstances, IL-12 p40 homodimers instead of bioactive IL-12 p70 are secreted more by antigen-presenting cells, which have been shown to act as antagonists of IL-12 receptors (38) and to inhibit IL-12-dependent immune functions in vivo $(39,40)$. Although our results showed a decrease in IL-12 p40 level after G-CSF administration, these results might indicate a multiplier effect between G-CSF and chemotherapy. Moreover, Hartung et al. reported that TNF- $\alpha$, IL-12, and IFN- $\gamma$ release by whole blood in response to endotoxin (lipopolysaccharide) was reduced in all filgrastim-treated donors (41). IL-12 added in vitro to lipopolysaccharide-stimulated blood of filgrastim-treated donors restored IFN- $\gamma$ and TNF- $\alpha$ release, suggesting that the anti-inflammatory effect of G-CSF is exerted through IL-12 
suppression.

Recently, the Dutch-Belgian Hemato-Oncology Coperative Group (HOVAN) group compared the effect of the cyclophosphamide, doxorubicin, vincristine, and prednisolone (CHOP) regimen given every 3 weeks with the effect of the same regimen plus G-CSF in elderly patients with aggressive non-Hodgkin's lymphoma in a randomized study (42). They found that the survival rate of patients who received the CHOP plus G-CSF regimen was better than that of patients who received the CHOP regimen. In the present study, the survival rate of patients at clinical stages III and IV who received chemotherapy with G-CSF was better than that of patients who received chemotherapy without G-CSF. Also, IL-12 p40 level was significantly decreased in the chemotherapy with G-CSF group. We cannot explain the association between good survival rate and decrease in IL-12 p40 level. However, administration of G-CSF appears to influence survival rate by reducing immunosuppressive IL-12 p40 production in advanced-stage NHL patients. 


\section{References}

1. Lamont AG., Adorini L. IL-12: a key cytokine in immune regulation. Immunol Today 1996; 17 : 214-217.

2. Trinchieri G. Interleukin-12: a proinflammatory cytokine with immunoregulatory functions that bridge innate resistance and antigen-specific adaptive immunity. Annu Rev Immunol 1995; 13: $251-276$

3. Trinchieri G. Cytokines acting on or secreted by macrophages during intracellular infection (IL-10, IL-12, IFN- gamma). Curr Opin Immunol 1997; 9: 17-23.

4. Brunda MJ. Interleukin-12. J Leukoc Biol 1994; 55:280-288.

5. Zou JP, Yamamoto N, Fujii T, Takenaka H, Kobayashi M, Herrmann SH, Wolf SF, Fujiwara H, Hamaoka T. Systemic administration of rIL-12 induces complete tumor regression and protective immunity: response is correlated with a striking reversal of suppressed IFN-gamma production by anti-tumor T cells. Int Immunol 1995; 7:1135-1145.

6. Brunda MJ, Luistro L, Warrier RR, Wright RB, Hubbard BR, Murphy M, Wolf SF, Gately MK. Antitumor and antimetastatic activity of interleukin 12 against murine tumors. J Exp Med 1993; 178: $1223-1230$.

7. Robertson MJ, Ritz J. Interleukin 12: basic biology and potential applications in cancer treatment. Oncologist 1996; 1:88-97.

8. Okamura H, Tsutsi H, Komatsu T, Yutsudo M, Hakura A, Tanimoto T, Torigoe K, Okura T, Nukada Y, Hattori K, Akita K, Namba M, Tanabe F, Konishi K, Fukuda S, Kurimoto M. Cloning of a new cytokine that induces IFN-gamma production by T cells. Nature 1995;378: 88-91.

9. Stern AS, Podlaski FJ, Hulmes JD, Pan YE, Quinn PM, Wokitzky AG, Familletti PC, Stremlo DL, Truitt T, Chizzonite R, Gately MK. Purification to homogeneity and partial characterization of cytotoxic ltymphocyte maturation factor from human B- lymophoblastoid cells. Proc Natl Acad Sci 
USA $1990 ; 87: 6808-6812$.

10. Sieburth D, Jabs EW, Warrington JA, Li X, Lasota J, LaForgia S, Kelleher K, Huebner K, Wasmuth JJ, Wolf SF. Assignment of genes encoding a unique cytokine (IL-12) composed of two unrelated subunits to chromosomes 3 and 5. Genomics 1992; 14:59-62.

11. Trinchieri G. Interleukin -12: a cytokine at the interface of inflammation and immunity. Adv Immunol 1998; 70: 83-243.

12. Mattner F, Fischer S, Guckes S, Jin S, Kaulen H, Schmitt E, Rude E, Germann T. The interleukin-12 subunit p40 specifically inhibits effects of the interleukin-12 heterodimer. Eur J Immunol 1993;23:2202-2208.

13. Gillessen S, Carvajal D, Ling P, Podlaski FJ, Stremlo DL, Familletti PC, Gubler U, Presky DH, Stern AS, Gately MK. Mouse interleukin-12 (IL-12) p40 homodimer: a potent IL-12 antagonist. Eur J Immunol 1995;25: 200-206.

14. Demetri GD, Griffin JD. Granulocyte colony-stimulating factor and its receptor. Blood 1991; 78: 2791-2808

15. Dale DC, Liles WC, Summer WR, Nelson S. Review. granulocyte colony-stimulating factorrole and relationships in infectious diseases. J Infect Dis 1995; 172: 1061-1075.

16. Hartung T, Docke WD, Gantner F, Krieger G, Sauer A, Stevens P, Volk HD, Wendel A. Effects of granulocyte colony-stimulating factor treatment on ex vivo blood cytokine response in human volunteers. Blood 1995; 85: 2482-2489.

17. Pollmacher T, Korth C, Mullington J, Schreiber W, Sauer J, Vedder H, Galanos C, Holsboer F. Effects of granulocyte colony-stimulating factor on plasma cytokine and cytokine receptor levels and on the in vivo host response to endotoxin in healthy men. Blood 1996; 87:900-905. 18. Toki S, Hiromatsu K, Aoki Y, Makino M, Yoshikai Y. Protective effects of granulocyte colony-stimulating factor on endotoxin shock in mice with retrovirus-induced immunodeficiency 
syndrome. Cytokine 1997; 9: 781-786.

19. Villa P, Shaklee CL, Meazza C, Agnello D, Ghezzi P, Senaldi G. Granulocyte

colony-stimulating factor and antibiotics in the prophylaxis of a murine model of polymicrobial peritonitis and sepsis. J Infect Dis 1998; 178:471-477.

20. Weiss M, Moldawer LL, Schneider EM. Granulocyte colony-stimulating factor to prevent the progression of systemic nonresponsiveness in systemic inflammatory response syndrome and sepsis. Blood 1999; 93: 425-439.

21. Harris NL, Jaffe ES, Stein H, Banks PM, Chan JK, Cleary ML, Delsol G, De Wolf-Peeters C, Falini B, Gatter KC, Grogan TM, Isaacson PG, Knowles DM, Mason DY, Muller-Hermelink HK, Pileri SA, Piris MA, Ralfkiear E, Warnke RA. A revised European-American classification of lymphoid neoplasms: a proposal from the international lymphomas study group. Blood 1994; $84: 1361-92$.

22.Airoldi I, Guglielmino R, Ghiotto F, Corcione A, Facchetti P, Truini M, Pistoia V. Cytokine gene in neoplastic B cells from human mantle cell, follicular, and marginal zone lymphomas and in their postulated normal counterparts. Cancer Res 2001; 61: 1285-90.

23.Airoldi I, Guglielmino R, Carra G, Corcione A, Gerosa F, Taborelli G, Trinchieri G, Pistoia V. The interleukin-12 and interleukin-12 receptor system in normal and transformed human B lymphocytes. Haematologica 2002; 87: 434-442.

24. Schwaller J, Tobler A, Niklaus G, Hurwitz N, Hennig I, Fey MF, Borisch B. Interleukin-12 expression in human lymphomas and nonneoplastic lymphoid disorders. Blood 1995; 85: $2182-2188$.

25. Hsu SM, Waldron JW Jr, Hsu PL, Hough AJ Jr. Cytokines in malignant lymphomas: review and prospective evaluation. Human Pathol 1993; 24:1040-1057.

26. Fior R, Vita N, Raphael M, Minty A, Maillot MC, Crevon MC, Caput D, Biberfeld P, Ferrara P, 
Galanaud P. Interleukin-13 gene expression by malignant and EBV-transformed human B lymphocytes. Eur Cytokine Netw 1994; 5:593-600.

27. Ford R, Tamayo A, Martin B, Niu K, Claypool K, Cabanillas F, Ambrus J Jr. Identification of B-cell growth factors (interleukin-14; high molecular weight-B-cell growth factors) in effusion fluids from patients with aggressive B-cell lymphomas. Blood 1995; 86:283-293.

28. Bost KL, Bieligk SC, Jaffe BM. Lymphokine m RNA expression by transplantable murine B lymphocytic malignancies. Tumor-derived IL-10 as a possible mechanism for modulating the anti-tumor response. J Immunol 1995; 154:718-729.

29. Benjamin D, Sharma V, Kubin M, Klein JL, Sartori A, Holliday J, Trinchieri G. IL-12 expression in AIDS-related lymphoma B cell lines. J Immunol 1996; 156: 1626-1637.

30. Jones EA, Pringle JH, Angel CA, Rees RC. Th1/Th2 cytokine expression and its relationship with tumor growth in B cell non-Hodgkin's lymphoma (NHL). Leuk Lymphoma 2002; 43:

1313-1321.

31. Arpinati M, Green CL, Heimfeld S, Heuser JE, Anasetti C. Granulocyte-colony stimulating factor mobilizes T helper 2-inducing dendritic cells. Blood 2000; 95:2484-2490.

32. Pan L, Delmonte J Jr, Jalonen CK, Ferrara JL. Pretreatment of donor mice with granulocyte colony-stimulating factor polarizes donor T lymphocytes toward type-2 cytokine production and reduces severity of experimental graft-versus-host disease. Blood 1995; 86: 4422-4429.

33. Mielcarek M, Martin PJ, Torok-Storb B. Suppression of alloantigen-induced T-cell proliferation by CD14+ cells derived from granulocyte colony-stimulating factor-mobilized peripheral blood mononuclear cells. Blood 1997; 89:1629-1634.

34. Mielcarek M, Graf L, Johnson G, Torok-Storb B. Production of interleukin-10 by granulocyte colony-stimulating factor-mobilized blood products: a mechanism for monocyte-mediated suppression of T-cell proliferation. Blood 1998; 92:215-222. 
35. Egi H, Hayamizu K, Kitayama T, Ohmori I, Okajima M, Asahara T. Downreguration of both interleukin-12 and interleukin-2 in heart allografts by pretransplant host treatment with granulocyte colony-stimulating factor and tacrolimus. Cytokine 2002; 18:164-167.

36. Ohmori I, Hayamizu K, Kitayama T, Egi H, Aihaiti X, Asahara T. Downreguration of interleukin-12p35 and upregulation of interleukin-12p40 mRNA expression in heart allografts by blood transfusion from granulocyte colony-stimulating factor-treated donos. Cytokine 2003; 21:27-31.

37. Kitayama T, Hayamizu K, Egi H, Ohmori I, Yoshimitsu M, Asahara T. Facilitation of tacrolimus-induced heart-allograft acceptability by pretransplant host treatment with granulocyte colony-stimulating factor: interleukin-12-restricted suppression of intragraft monokine m RNA expression. Transplantation 2003; 75: 553-556.

38.Gately MK, Renzetti LM, Magram J, Stern AS, Adorini L, Gubler U, Presky DH. The interleukin-12/interleukin-12-receptor system: role in normal and pathologic immune responses. Ann Rev Immunol 1998; 16: 495-521.

39. Kato K, Shimozato O, Hoshi K, Wakimoto H, Hamada H, Yagita H, Okumura K. Local production of the $\mathrm{p} 40$ subunit of interleukin 12 suppresses T-helper 1-mediated immune responses and prevents allogeneic myoblast rejection. Proc Natl Acad Sci USA 1996; 93: 9085-9089.

40. Rothe H, O'Hara RM Jr, Martin S, Kolb H. Suppression of cyclophosphamide induced diabetes development and pancreatic Th1 reactivity in NOD mice treated with the interleukin (IL)-12 antagonist IL-12 (p40) 2. Diabetologia 1997; 40: 641-646.

41. Hartung T, Doecke WD, Bundschuh D, Foote MA, Gantner F, Hermann C, Lenz A, Milwee S, Rich B, Simon B, Volk HD, von Aulock S, Wendel A. Effect of filgrastim treatment on inflammatory cytokines and lymphocyte functions. Clin Pharmacol Ther 1999; 66: 415-424. 42. Doorduijn JK, van der Holt B, van Imhoff GW, van der Hem KG, Kramer MH, van Oers MH, 
Ossenkoppele GJ, Schaafsma MR, Verdonck LF, Verhoef GE, Steijaert MM, Buijt I, Uyl-de Groot CA, van Agthoven M, Mulder AH, Sonneveld P. CHOP compared with CHOP plus granulocyte colony-stimulating factor in elderly patients with aggressive non-Hodgkin's lymphoma. J Clin Oncol 2003; 21:3041-3050. 


\section{Figure legends}

Figure 1. Time course of IL-12 p40 and IL-12 Mix levels.

IL-12 p40 (Figure 1-a) and IL-12 Mix (Figure 1-b) levels were decreased after chemotherapy.

IL-12 p40 and IL-12 Mix levels in the G-CSF administration group were significantly decreased compared with the levels in the chemotherapy alone group at 10 days and 17 days after

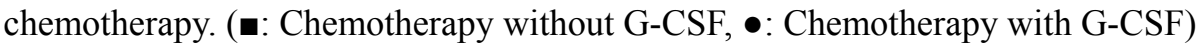

Figure 2. Changes in IL-12 p40 and IL-12 Mix levels with G-CSF or without G-CSF after chemotherapy in patients at clinical stages and .

IL-12 p40 level in the G-CSF administration group was significantly decreased on day 17 after chemotherapy (Figure 4-a) but IL-12 Mix level was not significantly different (Figure 4-b).

Chemotherapy without G-CSF, $\bullet$ : Chemotherapy with G-CSF)

Figure 3. Event- free survival.

a: Event- free survival (EFS) rates in the chemotherapy with G-CSF group (n=9) and chemotherapy without G-CSF group ( $\mathrm{n}=9$ ). EFS rates in the two groups were not significantly different.

b: Clinical stage and pathology. 
Table 1. Patients characteristics.

\begin{tabular}{|c|c|c|c|}
\hline \multirow{2}{*}{\multicolumn{2}{|c|}{$\overline{\text { Total evaluable patients }}$}} & \multirow{3}{*}{$\begin{array}{l}\text { Chemotherapy only group } \\
9 \\
6\end{array}$} & \multirow{3}{*}{$\begin{array}{l}\text { Chemotherapy+G-CSF group } \\
9 \\
4\end{array}$} \\
\hline & & & \\
\hline Sex & Male & & \\
\hline & Female & 3 & 5 \\
\hline Medi & age (range) & $52(31-81)$ & $57(43-72)$ \\
\hline \multicolumn{4}{|c|}{ PS before treatment } \\
\hline & 0 & 4 & 6 \\
\hline & 1 & 4 & 1 \\
\hline & 2 & 0 & 0 \\
\hline & 3 & 0 & 2 \\
\hline & 4 & 1 & 0 \\
\hline
\end{tabular}

Clinical stage

$\begin{array}{lll}\text { I } & 2 & 1 \\ \text { II } & 3 & 2 \\ \text { III } & 3 & 1 \\ \text { IV } & 1 & 5\end{array}$

B symptom

$\begin{array}{lll}(+) & 0 & 3 \\ (-) & 9 & 5 \\ \text { Unknown } & & 1\end{array}$

Working Formulation grading

$\begin{array}{lll}\text { Low } & 5 & 1 \\ \text { Intermediate } & 4 & 8\end{array}$

IPI

$\begin{array}{lll}\text { Low } & 3 & 1 \\ \text { Low intermediate } & 6 & 5 \\ \text { High intermediate } & 0 & 1 \\ \text { High } & 0 & 2\end{array}$

Prognosis

$\begin{array}{lll}\text { CR } & 6 & 7 \\ \text { PR } & 3 & 1 \\ \text { NC } & 0 & 1 \\ \text { PD } & 0 & 0\end{array}$


Table 2. Serum IL-12 levels in healthy volunteers and NHL patients.

\begin{tabular}{lll}
\multicolumn{1}{c}{ IL-12 p40 } & \multicolumn{1}{c}{ IL-12 Mix } \\
\hline Healthy volunteers $(\mathrm{n}=8)$ & $76.4 \pm 25.3$ & $48.5 \pm 33.4$ \\
Patients (n=28) & $191.2 \pm 150.0^{*}$ & $277.4 \pm 274.5^{*}$ \\
Clinical stage & & \\
$\quad$ I $-\mathrm{II}(\mathrm{n}=11)$ & $131.7 \pm 107.3$ & $118.6 \pm 96.1$ \\
$\quad$ III $-\mathrm{IV}(\mathrm{n}=17)$ & $229.6 \pm 163.7^{*}$ & $380.2 \pm 304.6^{*}$ \\
\hline
\end{tabular}

* $\mathrm{p}<0.05$ 
Figure 1-a

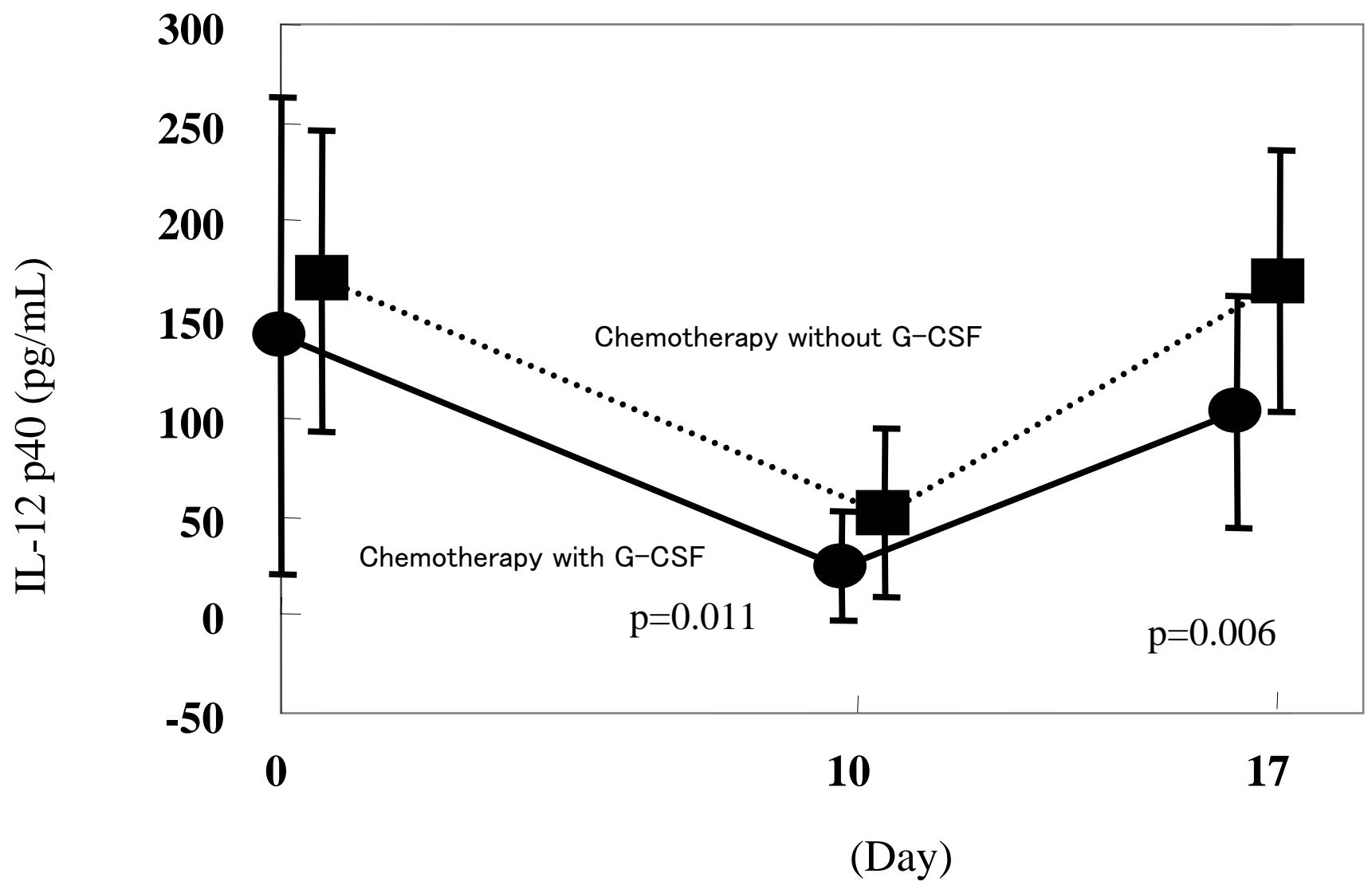


Figure 1-b

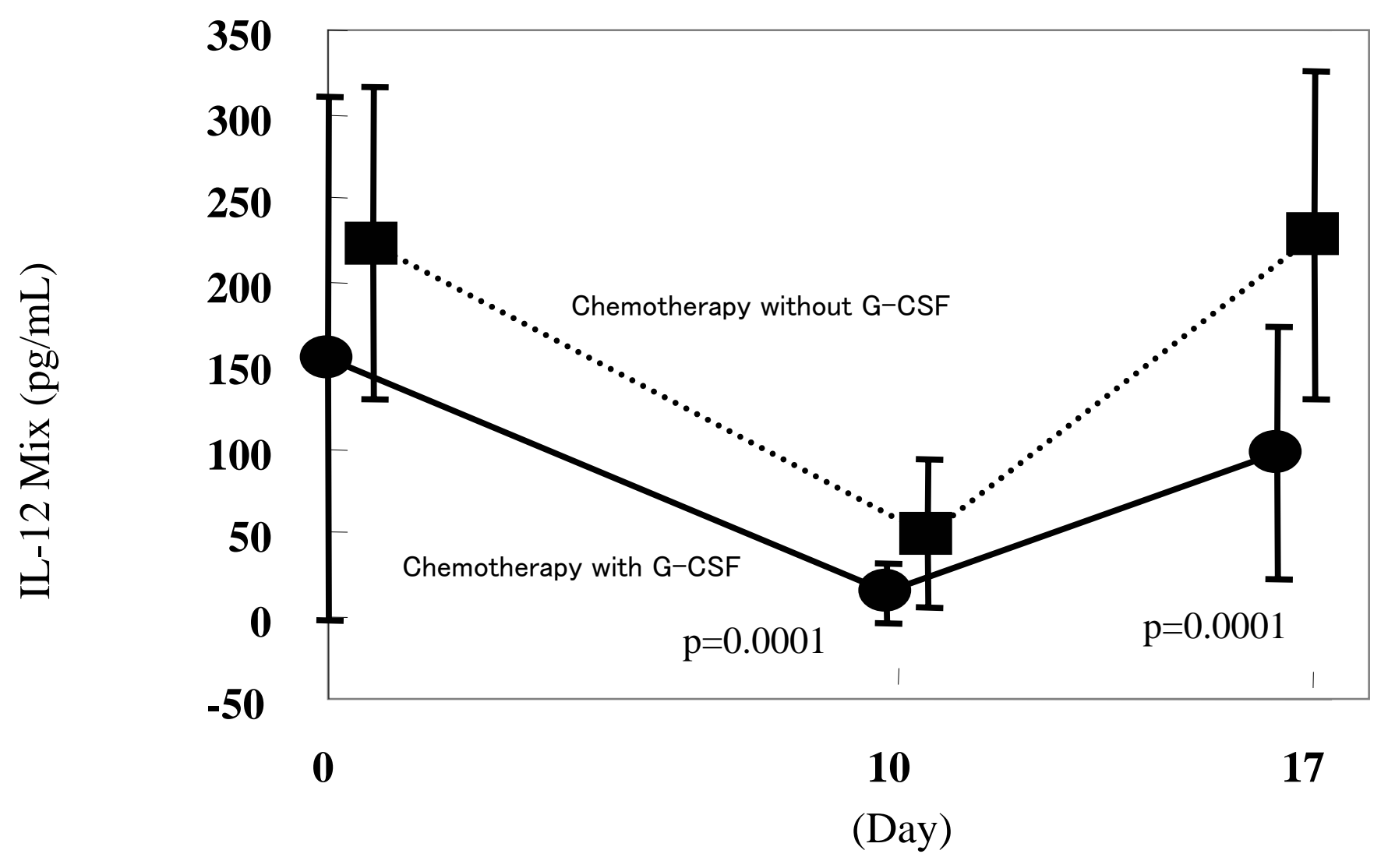


Figure.2-a

Clinical stage (I + II)

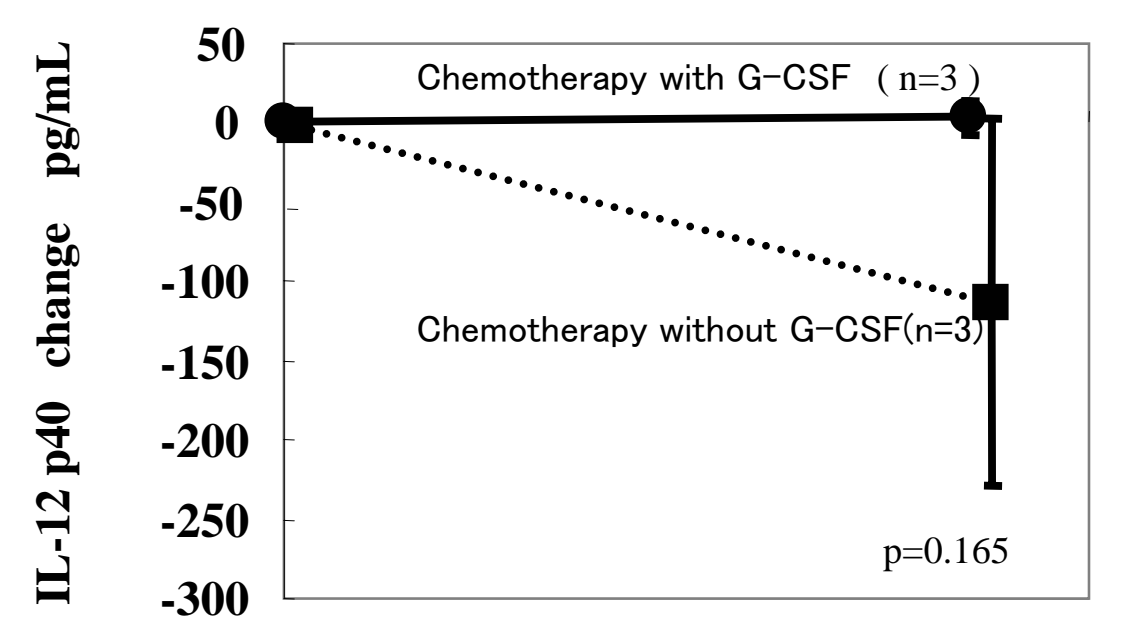

Day 0

Day 17

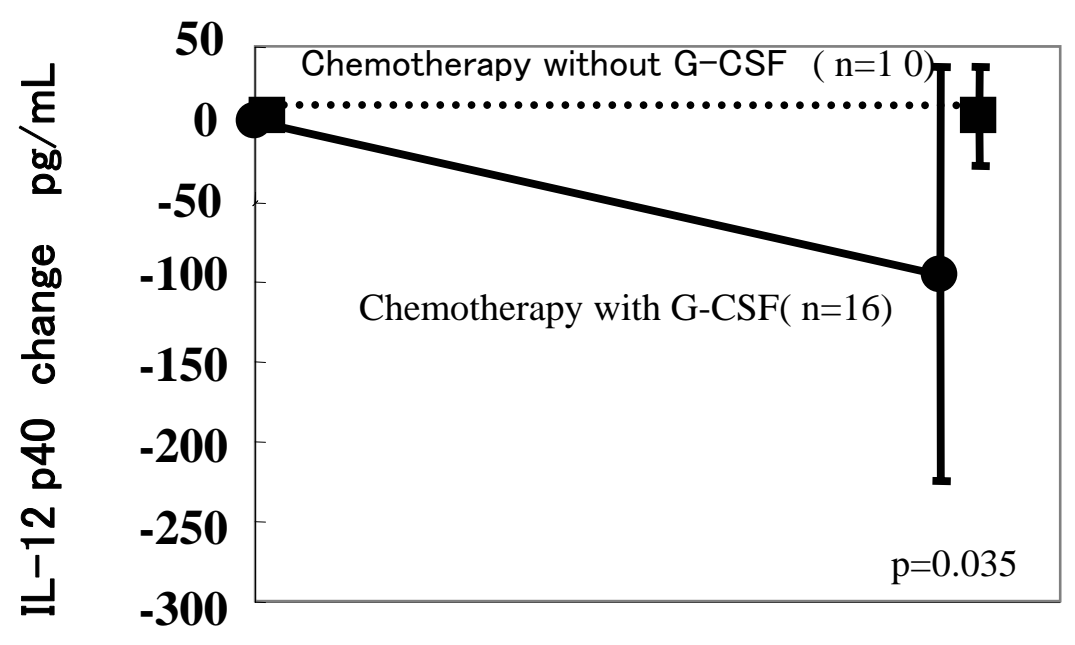

Day $0 \quad$ Day 17 
Figure.2-b

Clinical stage (I + II)

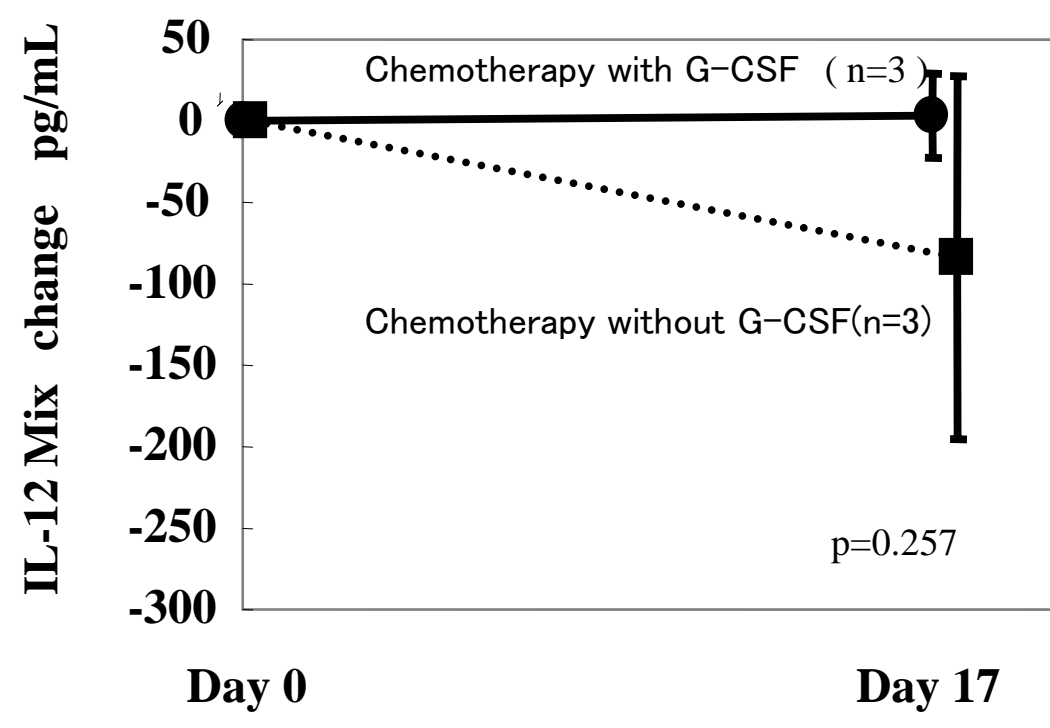

\section{Clinical stage (III + IV)}

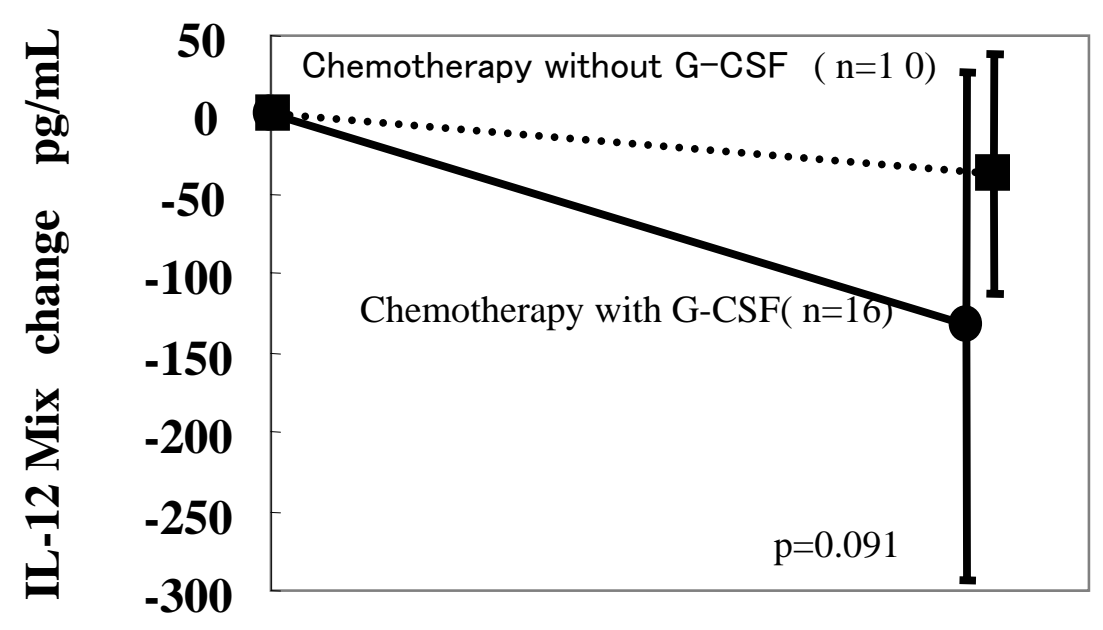

Day 0

Day 17 
Figure 3-a

Chemotherapy with G-CSF (n=9)

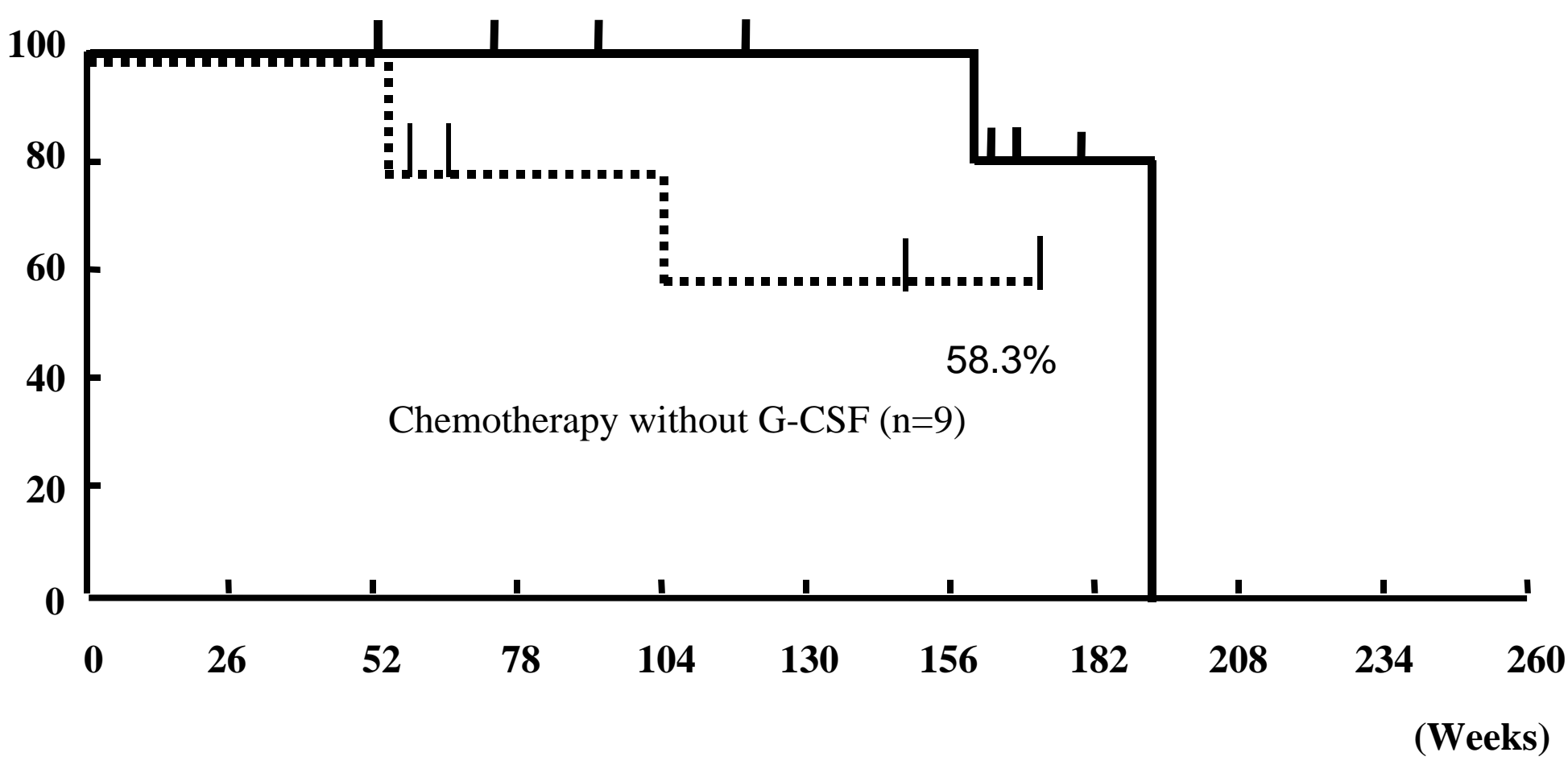


Figure 3-b.1:Clinical stage I and II .

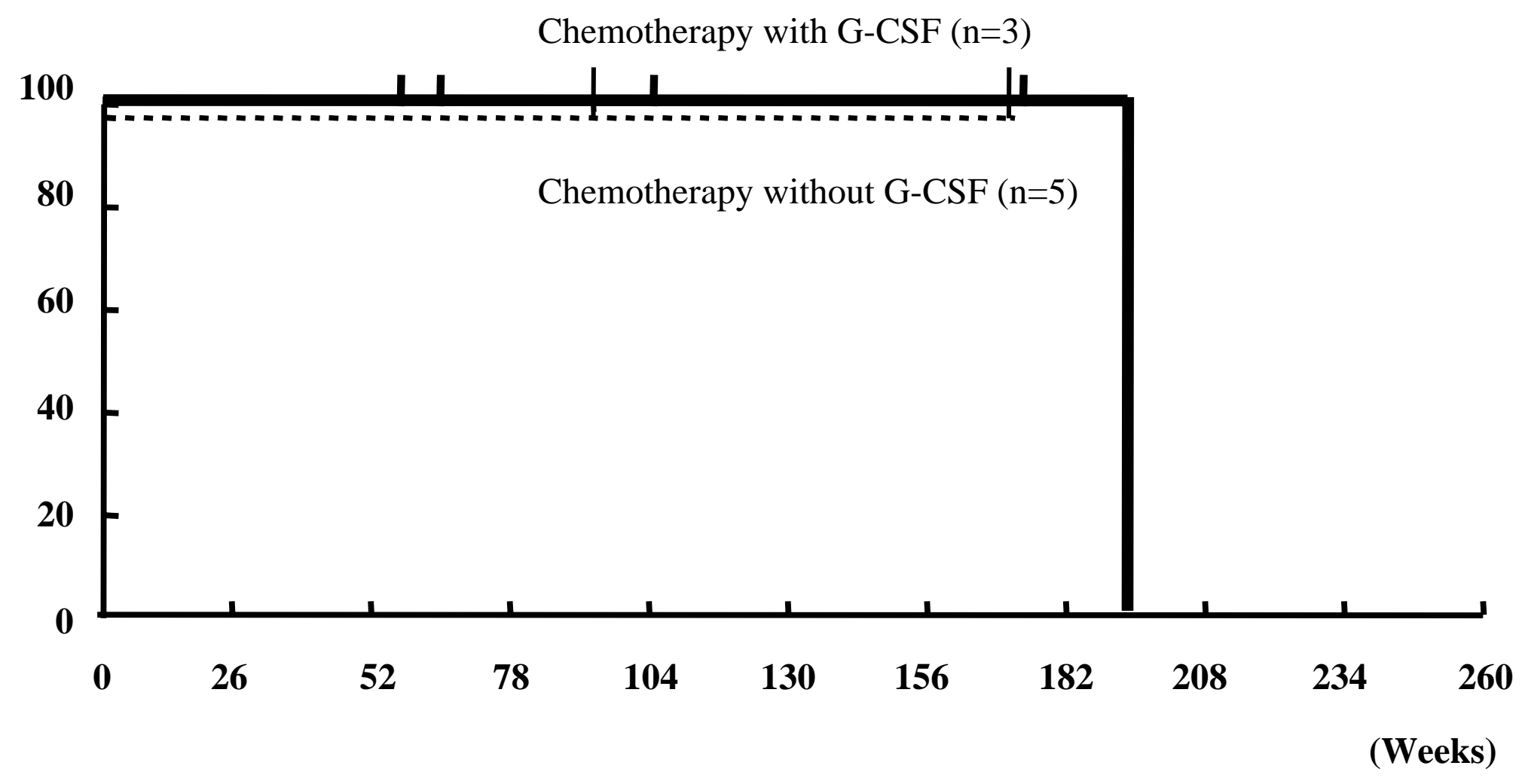


Figure 3-b.2:Clinical stage III and IV.

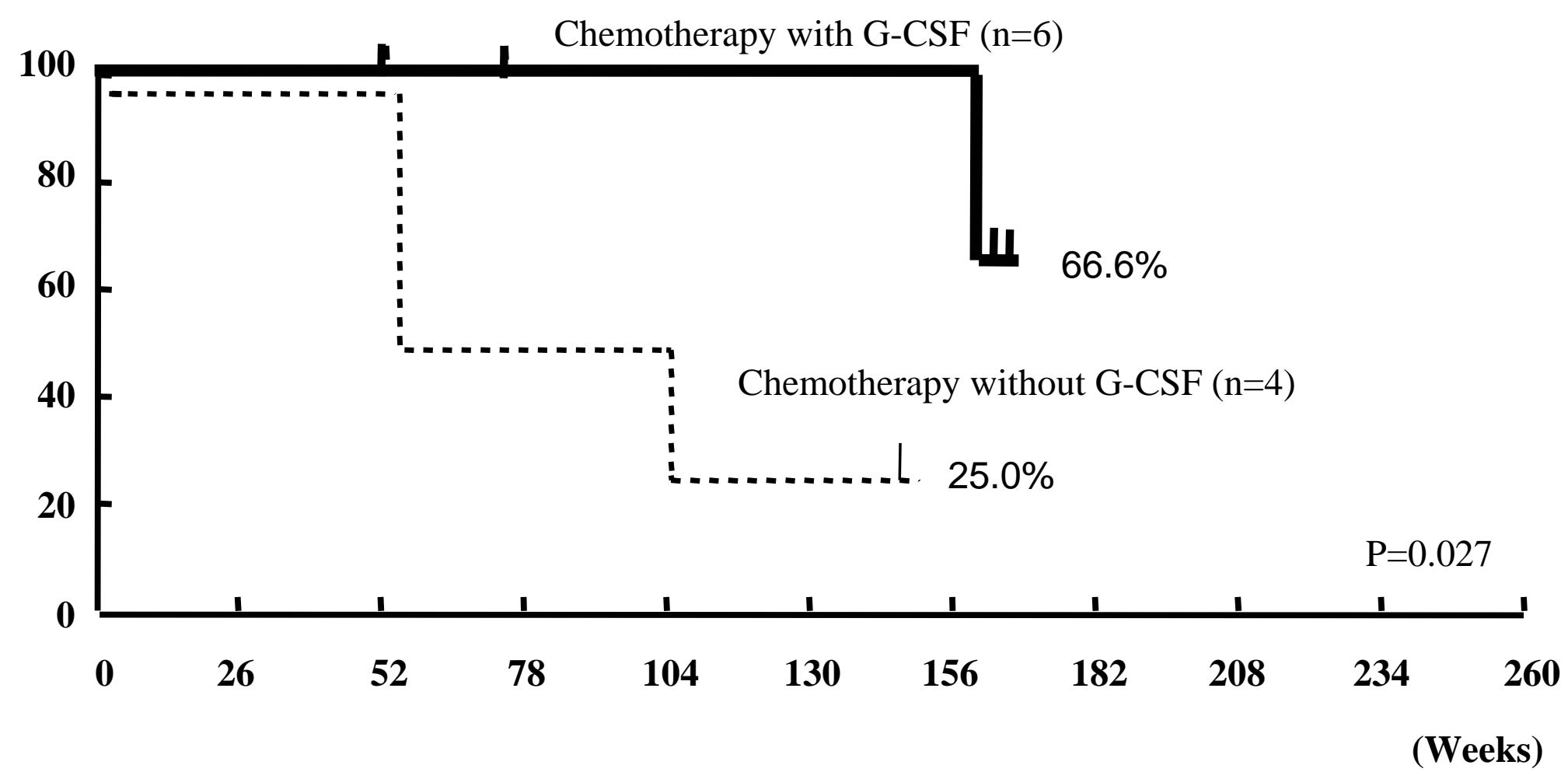


Figure 3-b.3:Low grade lymphoma.

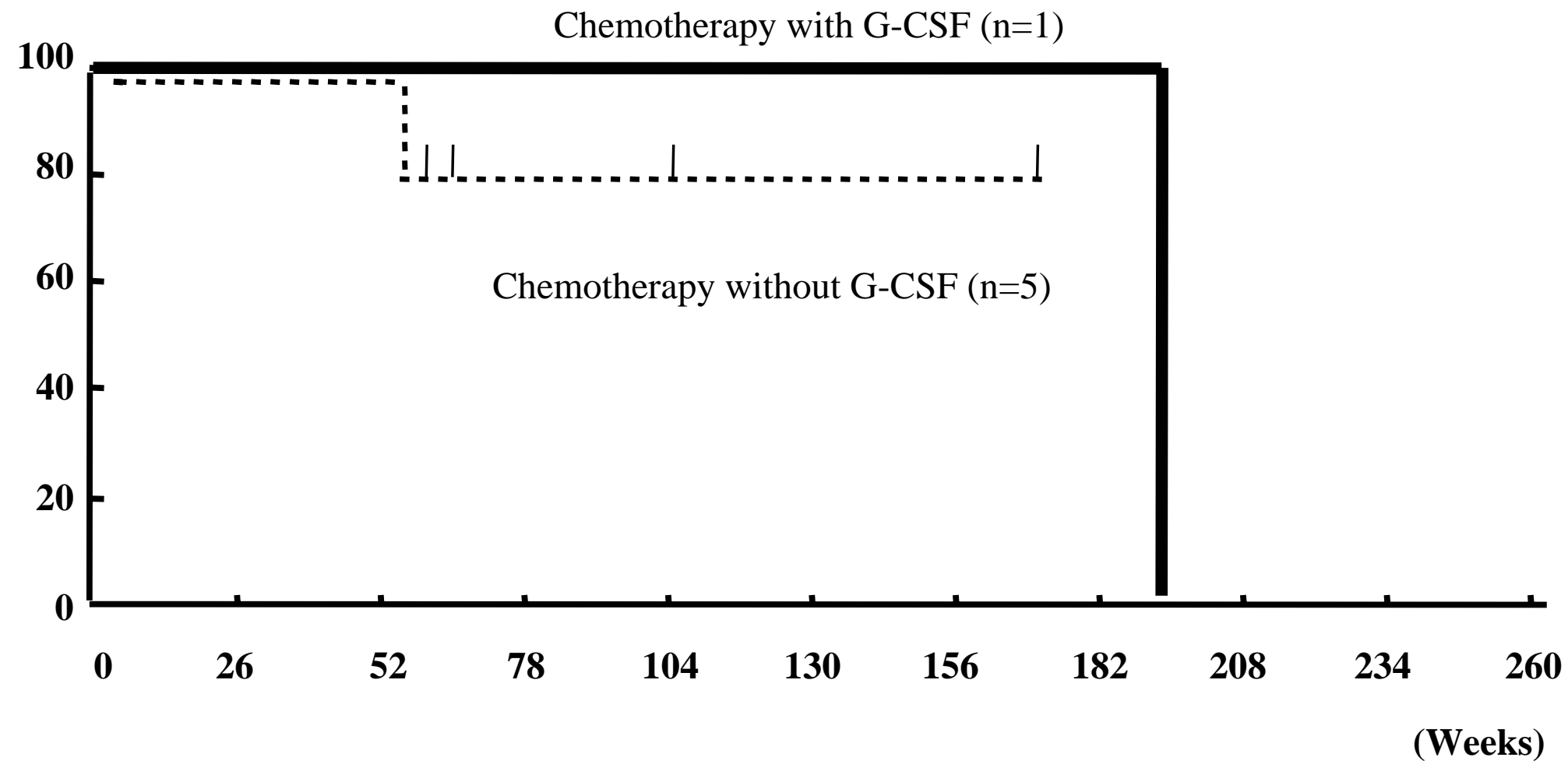


Figure 3-b.4:Intermediate grade lymphoma.

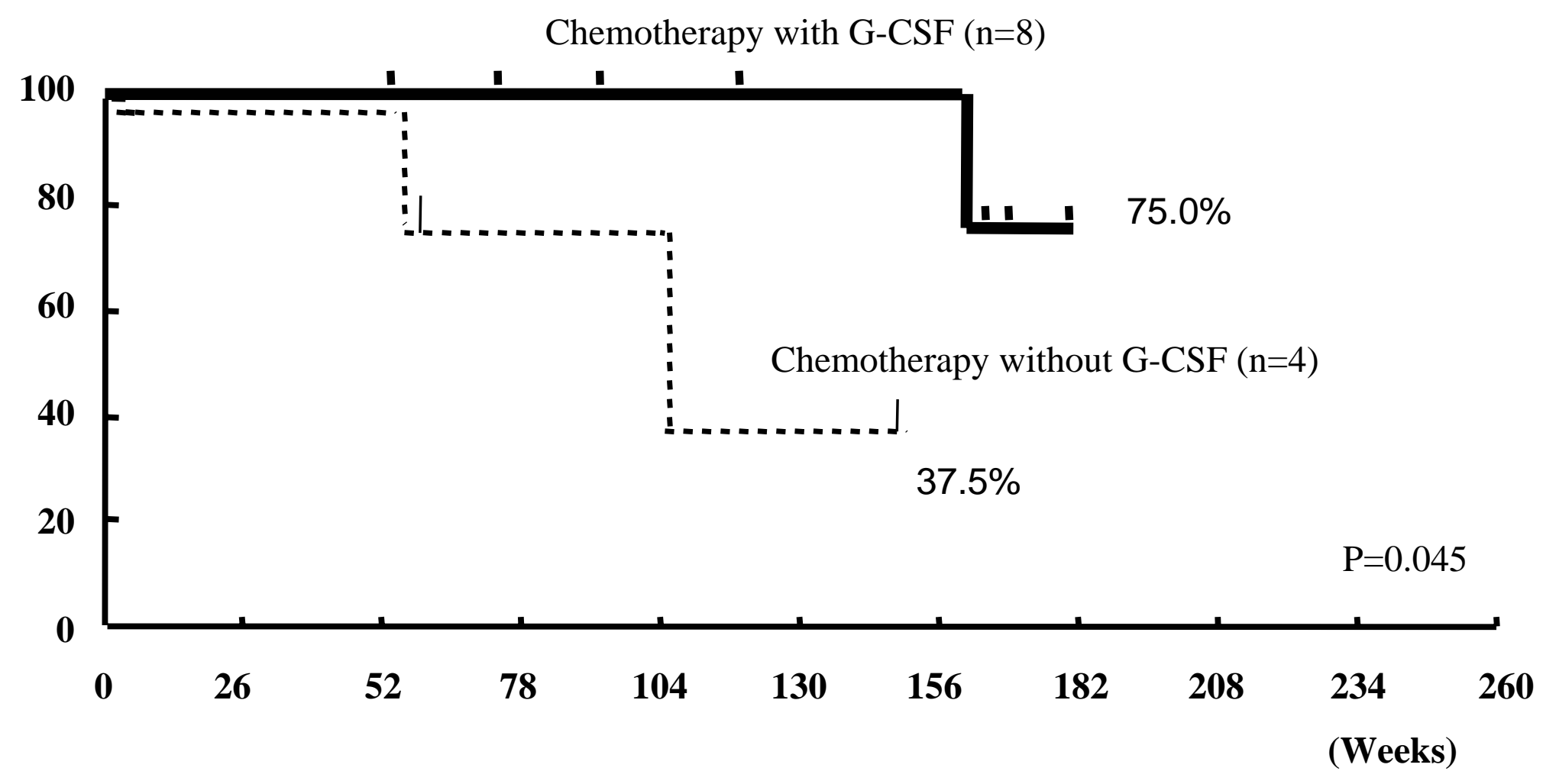

